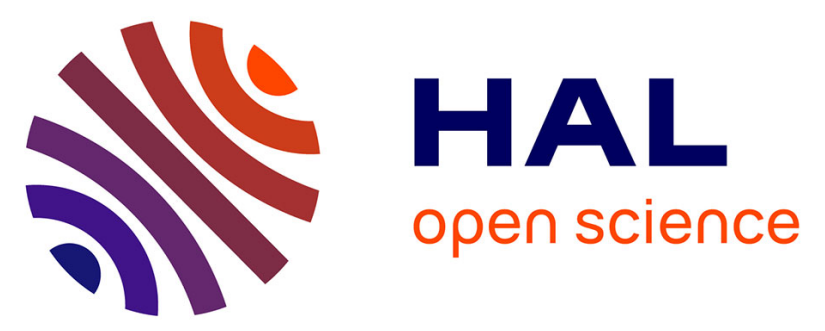

\title{
Deciphering the molecular basis of ferroportin resistance to hepcidin: Structure/function analysis of rare SLC40A1 missense mutations found in suspected hemochromatosis type 4 patients
}

M. Le Tertre, C. Ka, J. Guellec, I. Gourlaouen, C. Férec, I. Callebaut, G. Le $\mathrm{Gac}$

\section{To cite this version:}

M. Le Tertre, C. Ka, J. Guellec, I. Gourlaouen, C. Férec, et al.. Deciphering the molecular basis of ferroportin resistance to hepcidin: Structure/function analysis of rare SLC40A1 missense mutations found in suspected hemochromatosis type 4 patients. Transfusion Clinique et Biologique, 2017, 24 (4), 10.1016/j.tracli.2017.07.002 . hal-01679064

\section{HAL Id: hal-01679064 https://hal.sorbonne-universite.fr/hal-01679064}

Submitted on 9 Jan 2018

HAL is a multi-disciplinary open access archive for the deposit and dissemination of scientific research documents, whether they are published or not. The documents may come from teaching and research institutions in France or abroad, or from public or private research centers.
L'archive ouverte pluridisciplinaire HAL, est destinée au dépôt et à la diffusion de documents scientifiques de niveau recherche, publiés ou non, émanant des établissements d'enseignement et de recherche français ou étrangers, des laboratoires publics ou privés. 


\title{
Deciphering the molecular basis of ferroportin resistance to hepcidin: Structure/function analysis of rare SLC4OA1 missense mutations found in suspected hemochromatosis type 4 patients
}

\author{
Mécanismes de résistance de la ferroportine à l'hepcidine : analyses structure/fonction de mutations \\ faux-sens rares du gène SLC40A1 identifiées chez des patients présentant une surcharge en fer \\ typique de l'hémochromatose de type 4 \\ M. Le Tertre ${ }^{\mathrm{a}, \mathrm{b}, \mathrm{c}, *}$, C. Ka ${ }^{\mathrm{a}, \mathrm{b}, \mathrm{c}}, \mathrm{J}_{\text {. Guellec }}^{\mathrm{a}, \mathrm{b}, \mathrm{e}}, \mathrm{I}_{\text {. Gourlaouen }}^{\mathrm{a}, \mathrm{b}, \mathrm{d}}$, \\ C. Férec ${ }^{\text {a,c,d }}$, I. Callebaut ${ }^{\mathrm{f}}$, G. Le Gac ${ }^{\mathrm{a}, \mathrm{b}, \mathrm{c}, \mathrm{d}}$ \\ a Inserm UMR1078, faculté de médecine et des sciences de la santé, université Bretagne Loire-université de Bretagne Occidentale, IBSAM, IBRBS, 22, rue \\ Camille-Desmoulins, 29200 Brest, France \\ ${ }^{\mathrm{b}}$ Laboratory of Excellence GR-Ex, institut Imagine, 24, boulevard du Montparnasse, 75015, Paris, France \\ ${ }^{\mathrm{c}}$ Laboratoire de génétique moléculaire et histocompatibilité, hôpital Morvan, CHRU de Brest, 2, avenue Foch, 29200 Brest, France \\ d Établissement français du sang, Bretagne, site de Brest, 46 rue Félix-Le-Dantec, 29200 Brest, France \\ ${ }^{\mathrm{e}}$ Association Gaetan-Saleun, 29, rue Félix-Le-Dantec, 29200 Brest, France \\ ${ }^{\mathrm{f}}$ Muséum d'histoire naturelle, IRD UMR 206, case 115, IMPMC, Sorbonne universités-UMR CNRS 7590, UPMC université Paris 06, 4, place Jussieu, 75252 \\ Paris cedex 05, France
}

Available online 18 August 2017

\begin{abstract}
Genetic medicine applied to the study of hemochromatosis has identified the systemic loop controlling iron homeostasis, centered on hepcidinferroportin interaction. Current challenges are to dissect the molecular pathways underlying liver hepcidin synthesis in response to circulatory iron, HFE, TFR2, HJV, TMPRSS6 and BMP6 functions, and to define the major structural elements of hepcidin-ferroportin interaction. We built a first 3D model of human ferroportin structure, using the crystal structure of EmrD, a bacterial drug efflux transporter of the Major Facilitator Superfamily, as template. The model enabled study of disease-associated mutations, and guided mutagenesis experiments to determine the role of conserved residues in protein stability and iron transport. Results revealed novel amino acids that are critical for the iron export function and the hepcidin-mediated inhibition mechanism: for example, tryptophan 42, localized in the extracellular end of the ferroportin pore and involved in both biological functions. Here, we propose a strategy that is not limited to structure analysis, but integrates information from different sources, including human disease-associated mutations and functional in vitro assays. The first major hypothesis of this $\mathrm{PhD}$ thesis is that ferroportin resistance to hepcidin relies on different molecular mechanisms that are critical for ferroportin endocytosis, and include at least three fundamental steps: (i) hepcidin binding to ferroportin, (ii) structural reorganization of the $\mathrm{N}$ - and $\mathrm{C}$-ter ferroportin lobes, and (iii) ferroportin ubiquitination.
\end{abstract}

(C) 2017 Elsevier Masson SAS. All rights reserved.

Keywords: Iron metabolism; Hemochromatosis; Ferroportin; Hepcidin; Gain-of-function mutations

\section{Résumé}

L'étude des formes rares d'hémochromatose a contribué à une meilleure connaissance des mécanismes cellulaires et systémiques qui participent au maintien de l'homéostasie du fer et qui dépendent de l'axe hepcidine-ferroportine. Des questions fondamentales majeures restent posées sur les voies d'activation de la synthèse d'hepcidine en fonction de la quantité de fer plasmatique et de l'action à la surface des hépatocytes des protéines

\footnotetext{
* Corresponding author.

E-mail address: marlene.letertre@etudiant.univ-brest.fr (M. Le Tertre).
} 
HFE, TFR2, HJV, TMPRSS6 et BMP6, ainsi que sur les bases structurales de l'interaction hepcidine-ferroportine. Nous avons construit un premier modèle tridimensionnel de la ferroportine humaine à partir de la structure cristallographiée d'EmrD, un exportateur de drogues bactérien qui appartient à la famille des transporteurs secondaires MFS (« Major Facilitator Superfamily »). Cette modélisation a permis, en lien avec l'étude fonctionnelle de mutations faux-sens identifiées chez des patients présentant des phénotypes typiques d'hémochromatose de type 4, d'identifier des acides aminés qui ont une fonction critique dans la stabilité de la ferroportine, la fonction d'export du fer, ou la régulation par l'hepcidine. Le tryptophane en position 42 s'est, par exemple, révélé important à la fois pour la prise en charge du fer et l'endocytose de la ferroportine à la suite de la fixation de l'hepcidine. Nous proposons ici une stratégie qui combine analyses structurales, corrélations génotype/phénotype et tests fonctionnels in vitro. Ce travail de thèse vise à révéler les différents mécanismes moléculaires qui sous-tendent le processus de dégradation de la ferroportine. Ce processus semble comprendre trois étapes essentielles : (i) fixation de l'hepcidine à la ferroportine, (ii) réorganisation structurale des lobes $\mathrm{N}$ et C-terminaux de la ferroportine, et (iii) ubiquitination et internalisation du transporteur.

(C) 2017 Elsevier Masson SAS. Tous droits réservés.

Mots clés : Métabolisme du fer ; Hémochromatose ; Ferroportine ; Hepcidine ; Mutations « gain-de-fonction »

\section{Introduction}

Iron is essential to normal cell biology. As a component of heme, it is particularly important for erythropoiesis and oxygen transport. However, iron excess and "free" reactive iron is toxic. Body iron loss is insufficient, and intertwined mechanisms have evolved to maintain intracellular and systemic iron homeostasis. Ferroportin (FPN1, also referred to as SLC40A1, SLC11A1, MTP1 and IREG1) is the only known iron exporter in mammals and is considered a key coordinator of iron balance between the two compartments [1].

Ferroportin is expressed in all types of cell that handle major iron flow, including iron-recycling macrophages, absorptive enterocytes and storing hepatocytes (Fig. 1). Ferroportin is predominantly regulated by the liver-derived peptide hepcidin, which binds ferroportin on the cell surface, inducing internalization and degradation [2]. Hepcidin-ferroportin interaction is critical in both normal iron homeostasis and in common iron metabolism pathologies, including not only inherited disorders and iron overload but also non-genetic diseases and anemia [3].

\subsection{Regulation of ferroportin activity}

Ferroportin expression is regulated transcriptionally, posttranscriptionally, and post-translationally. At the cellular level, ferroportin synthesis is regulated via the iron-responsive element/iron regulatory proteins system. This system orchestrates the post-transcriptional regulation of several other important iron metabolism genes [4]. At the level of the organism, ferroportin is subject to post-translational downregulation via the liver-derived peptide hepcidin $[2,5]$. The molecular mechanism of hepcidinmediated ferroportin downregulation is not fully understood, but includes at least three fundamental steps:

- hepcidin binding to ferroportin, a step that involves amino acid residue p.Cys326 [6];

- ferroportin ubiquitination, a step that is thought to involve several lysine residues between positions 229 and 269 [7];

- ferroportin trafficking to the multivesicular body and degradation in the late endosome/lysosome compartment [8].

\subsection{Dichotomous patterns of human SLC4OA1 mutation}

In humans, most ferroportin mutations affect plasma membrane location and/or iron export ability. These loss-of-function mutations explain the classical reports of isolated serum ferritin elevation, relative plasma iron deficiency and preferential iron retention in cells of the reticuloendothelial system. This histological picture is commonly referred to as ferroportin disease [9].

In contrast, some SLC4OAl mutations do not impair the ability of ferroportin to export iron but result in partial to complete resistance to hepcidin. Patients with these gain-of-function mutations (hemochromatosis type 4) usually display histological and clinical presentations similar to those of the typical HFE-related hemochromatosis. More especially, due to greater flow of iron through iron-recycling macrophages and increased iron absorption, transferrin saturation is expected to be markedly elevated in these patients $[10,11]$.

\subsection{Ferroportin structure}

The structural organization of human ferroportin in the lipid bilayer is controversial. Wallace and collaborators reported the first model of the 3D structure of human ferroportin, with 12 predicted transmembrane helices built de novo (i.e., without homology). They subsequently fitted the model to experimental data, using Escherichia coli glycerol-3-phosphate (GlpT) transporter as template [12]. This template belongs to the Major Facilitator Superfamily (MFS), which is the largest group of secondary active membrane transporters, transporting a range of diverse substrates across membranes.

Bonaccorsi di Pati and collaborators described a fairly similar 3D model of ferroportin, based on threading/ab initio modeling [13]. This is not surprising, since, independently of the algorithms used, the Italian group predicted an inward-open conformation of the ferroportin iron transporter, using GlpT as template. They used a different MFS member, E. coli L-fucose proton symporter (FucP), to build an outward-open conformation of ferroportin. The switch between the two conformations is believed to drive iron transport across the plasma membrane. 


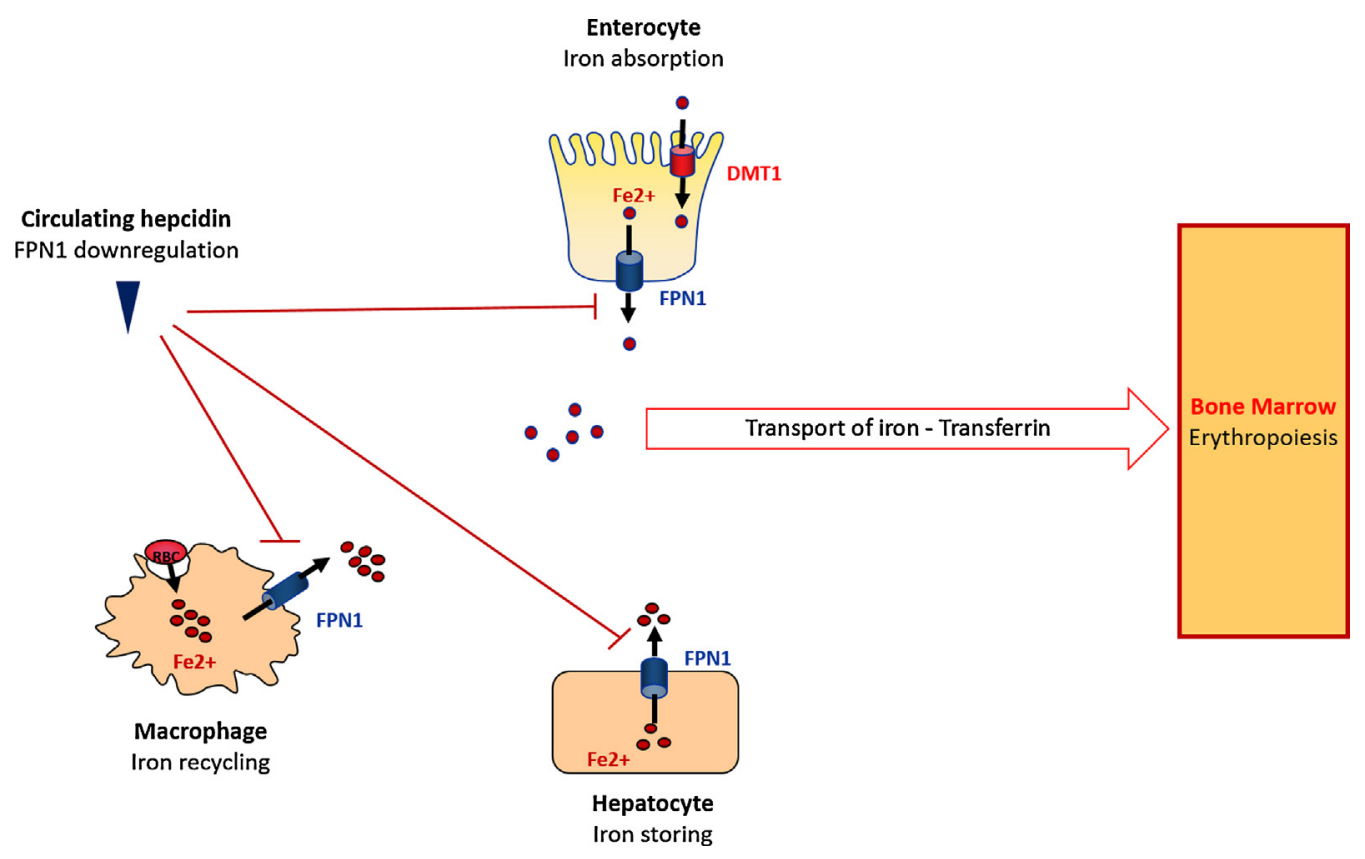

Fig. 1. Schematic representation of iron metabolism. Iron is partly imported in duodenal enterocytes by DMT1 (Divalent Metal Transporter 1), stored in hepatocytes and recycled from senescent red blood cells (RBC) in macrophages. Ferroportin (FPN1) mediates iron export into the bloodstream from iron-absorptive enterocytes, iron-recycling macrophages and iron-storing hepatocytes. The iron released into the plasma is transported by transferrin mainly to the bone marrow for erythropoiesis. Cellular iron export is regulated by hepcidin, which directly binds ferroportin and leads to its internalization and degradation.

We built a third 3D model of ferroportin, using a true comparative modeling approach, with sensitive methods for remote homology detection based on profile-profile alignments, and for alignment refinement (specific hydropathy profiles, deduced from hydrophobic cluster analysis), and validating the use of the crystal structure of one MFS antiporter, E. coli multidrug efflux protein D (EmrD), as template [14]. The structure of EmrD was determined in an occluded state. It is more compact than the crystal structure of GlpT, and the 12 transmembrane helices are arranged around a central pore.

A comparison of the 3D models of all possible states accompanying iron transport is essential for understanding the structure and biology of human ferroportin. In addition to the outwardand inward-facing states, MFS transporters are thought to form a transitional occluded state, in which the substrate is sequestered from both sides of the membrane. The recent report of the crystal structures of a putative bacterial homologue of ferroportin $(\mathrm{BbFPN})$ and the description of intra-domain conformational rearrangements during iron transport opens up new avenues for predicting the atomic details of the organization of ferroportin transmembrane helices and elucidating the detailed mechanisms of iron egress and hepcidin-mediated downregulation [15].

\section{Objectives}

Fundamental questions concerning ferroportin structure and biology remain to be answered. Based on structural and mutational analyses, we aim to:

- get insight into the interaction of hepcidin with ferroportin;
- characterize sequence invariants that may play a key role in conformational changes following hepcidin binding;

- improve interpretation of rare missense mutations found in suspected hemochromatosis patients.

Our research project is organized around three questions.

\subsection{How can the study of missense mutations identified in hemochromatosis patients help to reveal the molecular mechanisms underlying phenotypic variability and to shed light on protein function?}

As mentioned above, ferroportin gene mutations fall into 2 functional categories, responsible for different phenotypes (hemochromatosis type 4 vs. ferroportin disease). Most are unable to export iron (loss-of-function mutants; ferroportin disease), while others retain full capability but are insensitive to down-regulation by hepcidin (gain-of-function mutants; hemochromatosis type 4). Most ferroportin mutants are private, and most alter amino acids. This hinders both diagnosis and therapeutic decision-making, but structure-function studies may shed light on ferroportin function and its relationship with hepcidin. This is exemplified by the results of two previous studies: the first studied disease-causing mutations and revealed a clear dichotomy between gain-of-function mutations, which clustered in a region exposed to the extracellular milieu, accessible to hepcidin, and loss-of-function mutations, located at the cytoplasmic interface, where intracellular iron is delivered to ferroportin for export [14]; the second functionally characterized missense mutations of unknown significance and identified novel critical amino acids [11]. 
A

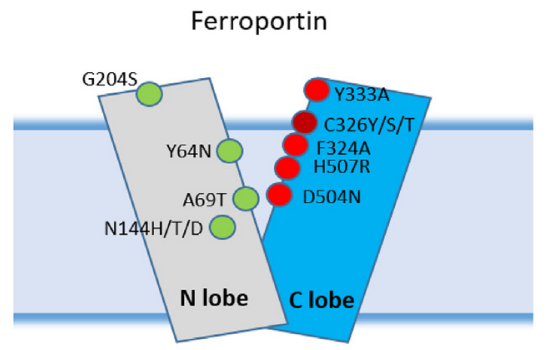

B

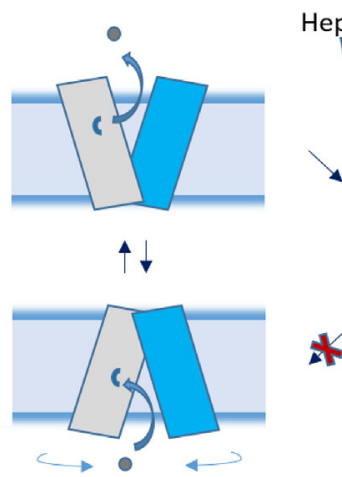

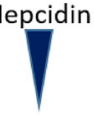
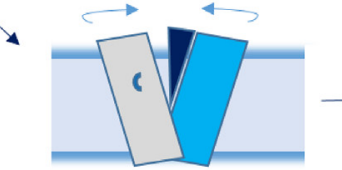

$\rightarrow$

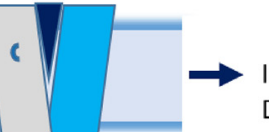

Internalization

Degradation

Ubiquitination

Fig. 2. Ferroportin down-regulation mechanisms. A. Gain-of-function ferroportin mutations identified in patients and functionally characterized. Substitution residues generating partial resistance of ferroportin to hepcidin are labeled in green, and those generating strong resistance in red. B. Model of hepcidin-mediated downregulation of ferroportin. Hepcidin binds to the ferroportin C-ter lobe, preventing its return to the inward conformation. Intracellular loop access is improved, enabling ubiquitination by ubiquitin ligases, triggering internalization and degradation of the iron exporter (adapted from Taniguchi et al., 2015 [15]).

\subsection{How to improve our knowledge of the hepcidin docking process?}

A critical point in the elucidation of the structure and biology of ferroportin was reached with the recent publication of the outward- and inward facing structures of a putative bacterial homologue of ferroportin (BbFPN). Taniguchi and collaborators supplied very important clues for identifying amino acids involved in the iron-binding site and for deciphering interaction networks between transmembrane helices in the outward- and inward-facing extreme structures. They further revealed the pivotal role of a central cavity that hosts the iron-binding site in the intra- and extra-cellular open states of BbFPN and is likely to be targeted by hepcidin in the outward-facing conformation of human ferroportin [15]. Although very important, these data are not the last word, but will serve as the starting point to predict atomic details of the organization of ferroportin transmembrane helices and to achieve accurate modeling of the human ferroportin 3D structure.

It noteworthy that missense mutations leading to the highest degrees of hepcidin resistance are located in the C-ter lobe of ferroportin [6,11,16-18], in the vicinity of Cys326, which is known to be essential to hepcidin/ferroportin interaction, while several missense mutations located in the $\mathrm{N}$-ter lobe have proved to induce partial resistance to hepcidin (Fig. 2A) $[6,16,19,20]$. Results, however, are conflicting, probably because different concentrations of hepcidin and different experimental procedures were used by the various groups. Furthermore, many missense mutations identified in patients with a typical hemochromatosis phenotype have not been evaluated functionally. Homogenous procedures are needed, to better discern gain-of-function mutations and confirm the existence of a functional dichotomy between the $\mathrm{N}$ - and $\mathrm{C}$-ter ferroportin lobes.

\subsection{How to identify ferroportin domains that are important for hepcidin-induced endocytosis?}

In general, ligand-induced endocytosis of plasma membrane transporters is triggered by a conformational change followed by phosphorylation and/or ubiquitination of their cytoplasmic segments [21]. Qiao et al. demonstrated that the ubiquitination of lysines between residues 229 and 269 in the third intracellular loop of ferroportin is the major signal for incorporation into the multivesicular body and degradation in the late endosome compartment. They further showed that the human ferroportin mutation p.Lys240Glu (K240E) caused resistance to hepcidin in vitro by interfering with ferroportin ubiquitination [7]. The specific details of ferroportin's cellular internalization process, including which ubiquitin-binding adaptor proteins may be involved, remain to be determined. In addition, nothing is yet known about the conformational changes that result from the interaction of hepcidin with ferroportin.

The fact that several missense mutations in the $\mathrm{N}$-ter lobe are associated with partial resistance to hepcidin without affecting the primary docking step [6] suggests that local changes in the first six helices play an important role (Fig. 2B). Here, we plan to functionally characterize 10 missense mutations located in transmembrane helices $1,2,4,5$ and 6 . This could help identify inter-domain interactions and residues that are critical for 
hepcidin-induced endocytosis, in a step that depends on hepcidin binding and comes before ubiquitination of lysines between residues 229 and 269 .

\section{Experimental procedures}

\subsection{Genetic studies}

In recent years, we contributed to reporting a handful of new mutations and disease phenotypes in patients with iron overload. We will capitalize on our expertise to investigate new SLC4OA1 missense mutations in patients with well-defined phenotypes. This will be facilitated by a national medical research program (PHRC) to determine the prevalence and severity of ferroportinassociated iron overload. Eighteen missense mutations, found in 44 French patients, have already been reported and functionally characterized [11]. Five missense mutations are still under investigation, and we can confidently predict that a few others will be identified in the coming two years.

\subsection{Functional in vitro testing}

To test the degree of resistance of the ferroportin variants to hepcidin, we will use Western blot analysis, flow cytometry and measurements of radiolabeled ${ }^{55} \mathrm{Fe}$. We will use the HEK293T cells as a cellular model to transiently or stably (tetracyclin-inducible system) overexpress ferroportin, while human hepcidin will be produced in stably transfected Hep3B cells. This will enable us to perform co-culture experiments and improve our ability to reveal subtle differences between mutations that cause resistance to hepcidin. A C-ter biotinylated hepcidin synthetic peptide will be used in pull-down and Western blotting experiments to test the interaction between hepcidin and ferroportin mutants. ${ }^{125}$ I-Hepcidin uptake experiments and global analysis of lysine ubiquitination will be performed to investigate amino acids that do not directly interact with hepcidin but could be involved in ferroportin endocytosis.

\subsection{Structural studies}

We will seek to provide a refined model of human ferroportin despite a relatively low level of sequence identity (24\%) with the bacterial template. This will be completed by a moleculardocking approach to study the interaction between hepcidin and ferroportin. This theoretical analysis, combined with experimental testing, will benefit from our past experience in membrane protein modeling (e.g., CFTR) [22,23].

\section{Milestones}

- M1- Accurate structure prediction of human ferroportin;

- M2- Better definition of the hepcidin-binding site on ferroportin;

- M3- Identification of the functional network (key residues and interactions) that orchestrate hepcidin-induced ferroportin endocytosis;
- M4- Better understanding of the molecular and physiological bases of hemochromatosis, by characterizing new mutations and reporting well-defined phenotypes.

\section{Disclosure of interest}

The authors declare that they have no competing interest.

\section{References}

[1] Hentze MW, Muckenthaler MU, Galy B, Camaschella C. Two to tango: regulation of mammalian iron metabolism. Cell 2010;142:24-38.

[2] Nemeth E, Tuttle MS, Powelson J, Vaughn MB, Donovan A, Ward DM, et al. Hepcidin regulates cellular iron efflux by binding to ferroportin and inducing its internalization. Science 2004;306:2090-3.

[3] Ganz T, Nemeth E. The hepcidin-ferroportin system as a therapeutic target in anemias and iron overload disorders. Hematol Am Soc Hematol Educ Program 2011;2011:538-42.

[4] Muckenthaler MU, Galy B, Hentze MW. Systemic iron homeostasis and the iron-responsive element/iron-regulatory protein (IRE/IRP) regulatory network. Annu Rev Nutr 2008;28:197-213.

[5] Ganz T. Hepcidin and iron regulation, 10 years later. Blood 2011;117:4425-33.

[6] Fernandes A, Preza GC, Phung Y, De Domenico I, Kaplan J, Ganz T, et al. The molecular basis of hepcidin-resistant hereditary hemochromatosis. Blood 2009;114:437-43.

[7] Qiao B, Sugianto P, Fung E, del-Castillo-Rueda A, Moran-Jimenez M-J, Ganz T, et al. Hepcidin-induced endocytosis of ferroportin is dependent on ferroportin ubiquitination. Cell Metab 2012;15:918-24.

[8] De Domenico I, Ward DM, Langelier C, Vaughn MB, Nemeth E, Sundquist WI, et al. The molecular mechanism of hepcidin-mediated ferroportin down-regulation. Mol Biol Cell 2007;18:2569-78.

[9] Pietrangelo A. The ferroportin disease. Blood Cells Mol Dis 2004;32:131-8

[10] Anderson GJ, McLaren GD. Iron physiology and pathophysiology in humans. New York: Humana Press; 2012.

[11] Callebaut I, Joubrel R, Pissard S, Kannengiesser C, Gérolami V, Ged $\mathrm{C}$, et al. Comprehensive functional annotation of 18 missense mutations found in suspected hemochromatosis type 4 patients. Hum Mol Genet 2014;23:4479-90.

[12] Wallace DF, Harris JM, Subramaniam VN. Functional analysis and theoretical modeling of ferroportin reveals clustering of mutations according to phenotype. Am J Physiol Cell Physiol 2010;298:C75-84.

[13] Bonaccorsi di Patti MC, Polticelli F, Cece G, Cutone A, Felici F, Persichini $\mathrm{T}$, et al. A structural model of human ferroportin and of its iron binding site. FEBS J 2014;281:2851-60.

[14] Le Gac G, Ka C, Joubrel R, Gourlaouen I, Lehn P, Mornon J-P, et al. Structure-function analysis of the human ferroportin iron exporter (SLC4OA1): effect of hemochromatosis type 4 disease mutations and identification of critical residues. Hum Mutat 2013;34:1371-80.

[15] Taniguchi R, Kato HE, Font J, Deshpande CN, Wada M, Ito K, et al Outward- and inward-facing structures of a putative bacterial transitionmetal transporter with homology to ferroportin. Nat Commun 2015;6:8545.

[16] Drakesmith H, Schimanski LM, Ormerod E, Merryweather-Clarke AT, Viprakasit V, Edwards JP, et al. Resistance to hepcidin is conferred by hemochromatosis-associated mutations of ferroportin. Blood 2005; 106:1092-7.

[17] Mayr R, Griffiths WJH, Hermann M, McFarlane I, Halsall DJ, Finkenstedt A, et al. Identification of mutations in SLC4OAl that affect ferroportin function and phenotype of human ferroportin iron overload. Gastroenterology 2011;140:2056-63 [e1].

[18] Preza GC, Ruchala P, Pinon R, Ramos E, Qiao B, Peralta MA, et al. Minihepcidins are rationally designed small peptides that mimic hepcidin activity in mice and may be useful for the treatment of iron overload. J Clin Invest 2011;121:4880-8. 
[19] Praschberger R, Schranz M, Griffiths WJH, Baumgartner N, Hermann M, Lomas DJ, et al. Impact of D181V and A69T on the function of ferroportin as an iron export pump and hepcidin receptor. Biochim Biophys Acta 2014;1842:1406-12 [Mol Basis Dis]

[20] Détivaud L, Island M-L, Jouanolle A-M, Ropert M, Bardou-Jacquet E, Le Lan C, et al. Ferroportin diseases: functional studies, a link between genetic and clinical phenotype. Hum Mutat 2013;34:1529-36.

[21] Bonifacino JS, Traub LM. Signals for sorting of transmembrane proteins to endosomes and lysosomes. Annu Rev Biochem 2003;72:395-447.
[22] Mornon J-P, Lehn P, Callebaut I. Atomic model of human cystic fibrosis transmembrane conductance regulator: membrane-spanning domains and coupling interfaces. Cell Mol Life Sci 2008;65: 2594-612.

[23] Mornon J-P, Hoffmann B, Jonic S, Lehn P, Callebaut I. Full-open and closed CFTR channels, with lateral tunnels from the cytoplasm and an alternative position of the F508 region, as revealed by molecular dynamics. Cell Mol Life Sci 2015;72:1377-403. 